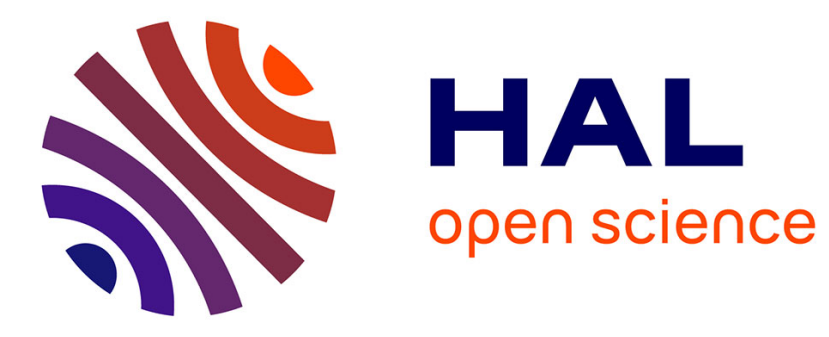

\title{
Preferences for fat and basic tastes in 3-, 6- and 12-month-old infants
}

Sophie Nicklaus, Claire Chabanet, Camille Schwartz, Emilie Szleper, Sylvie Issanchou

\section{- To cite this version:}

Sophie Nicklaus, Claire Chabanet, Camille Schwartz, Emilie Szleper, Sylvie Issanchou. Preferences for fat and basic tastes in 3-, 6- and 12-month-old infants. 19. annual Meeting of the society for the study of ingestive behavior, Jul 2011, Clearwater, Florida, United States. 1 p., 2011, 10.1016/j.appet.2011.05.235 . hal-01190354

\section{HAL Id: hal-01190354 https://hal.science/hal-01190354}

Submitted on 1 Sep 2015

HAL is a multi-disciplinary open access archive for the deposit and dissemination of scientific research documents, whether they are published or not. The documents may come from teaching and research institutions in France or abroad, or from public or private research centers.
L'archive ouverte pluridisciplinaire HAL, est destinée au dépôt et à la diffusion de documents scientifiques de niveau recherche, publiés ou non, émanant des établissements d'enseignement et de recherche français ou étrangers, des laboratoires publics ou privés. 
Preference for fatand basic tastes in 3-, 6-, 12- and 20-month-old infants: a longitudinal approach

S. Nicklaus*, C. Chabanet, C. Schwart, E. Szleper, S. Issanchou

Centre des Sciences du Goût et de I'Alimentation, UMR6265 CNRS, UMR1324 INRA, Université de Bourgogne, F-21000 Dijon, France

\section{Background}

Fat perception received recent interest, but fat preference in humans and in particular in infants is a matter of debate. In the newbom,
the sweet taste is liked and calms crying newboms and the bitter taste is rejected, but the taste of oil does not elicit any particular the sweet taste is liked and calms crying newboms and the bitter taste is rejected, but the taste of oil does not elicit any particular
reaction (Graillon \& al., 1997). In infants, milk intake is equivalent when fat content varies (Chan \& al., 1979; Woolridge $\&$ al., 1980), but sucking pattems are longer for fattier milks (Nysenbaum \& Smart, 1982).

\section{Method}

\section{$>$ Participants:}

- As part of OPAUNE, a longitudinal program studying the development of food preferences in boys) participated in the present study focusing 155 taste preferences (at $3 \mathrm{mo}, \mathrm{N}=193$; at $6 \mathrm{mo}, \mathrm{N}=245$ at $12 \mathrm{mo}, \mathrm{N}=266$; at $20 \mathrm{mo}, \mathrm{N}=253$ ).

$>$ Procedure: The method was adapted from previous studies (Kajiura \& al., 1992; Stein \& al., 2005) and was For each the local ethic al commiltee, informed consent was obtained fro

- A parent (generally the mother) and his/her infant participated in 2 videotaped sessions.

- For each stimulus, 4 bottles (water, taste solution, taste solution and water) were presented by the experimenter (Fig.1) who was blind to the stimulus

- At the age of 20 mo the infant could manipulate the bottle him/herself.

- The 5 tastes were presented in a balanced order; the fat stimulus was assessed after.

Each bottle contained $30 \mathrm{ml}$ at $3 \& 6 \mathrm{mo}$ and $50 \mathrm{ml}$ at $12 \& 20 \mathrm{mo}$, except for urea (15ml). Bottles were weighed before/afteringestion.

the content of each bottle was scored on a $5 \mathrm{pt}$-scale by the parent and by the experimenter.

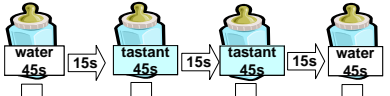

\section{Variables} Bottle 1 Bottle 2 Bottle 3 Bottle 4

Intake (volume, g) Botwe 1 Bottle 2 Bottle 3 Bottle 4 $\begin{array}{llllll}\text { Parent's judgment of liking (5-pt scale) } & \text { P. liking } 1 & \text { P. liking } 2 & \text { P. liking } 3 & \text { P. liking } 4\end{array}$ Ratios

$\begin{array}{llllllll}\text { Experimenter's judgment of liking (5-pt scale) } & \text { E. liking } 1 & \text { E. liking } 2 & \text { E. liking } 3 & \text { E. liking } 4\end{array}$

Fig.1: Procedure \& variables

\section{Analysis:}

mostricted to infants who complied and consumed at least $1.0 \mathrm{~g}$ from 2 bottles - For each measured variable, ratios were calculated as shown in Fig.1, to represent acceptance of the stimuli solution relatively to water. By definition each ratio may vary between 0 and 1 ; a ratio of 0.5 indicates indifference to the stimuli solution relatively to water. A ratio $>0.5$ indicates preference for Data were analyzed with a mixed model, using the $R$ statistic al package, for each ratio separately. For each ratio, the model hypothesized (i) a stimulus effect, (ii) a factorial or a quadratic effect of ag fimulus, with the same variance across stimuli for the individual intercepts and no comelation between stimuli.

\section{Disc ussion \& Conc lusion}

- Development of a preference for the salty taste between 3 and $6 \mathrm{mo}$ is in line with previous findings (Beauchamp \& al., 1986).

- The fact that evolutions were not uniform across tastes over the first year (i.e. changes in acceptance did not occur for bitter, and occurred differently for salty taste on one side and for sweet, sour and umami tastes on the other side) suggests that hese evolutions are not due to a general change in taste

\section{Intake} reased.

- For sweet, sour a
rejected at 20 mo it brings.

\section{Objectives}

$>$ To study acceptance of a fat solution and of basic taste solutions (sweet, salty, bitter, sour and umami) comparatively to water, in order to (

- To study the evolution of fat and taste acceptance longitudinally in the same infants at the ages of 3, 6, 12 and 20 months.

\section{Results}

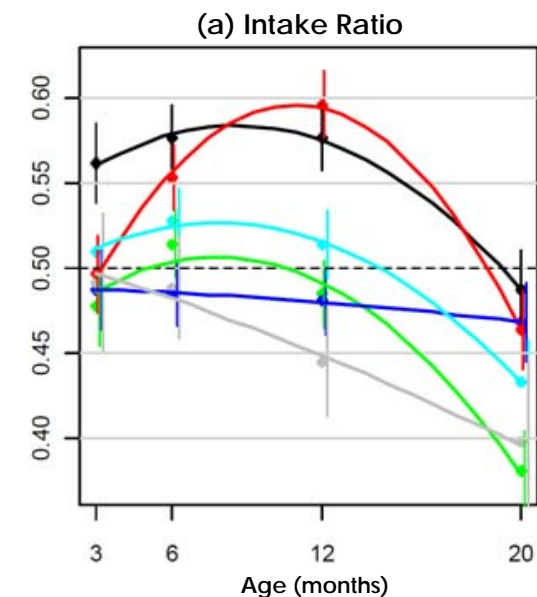

Age (months) (b) Parent's judgment Ratio

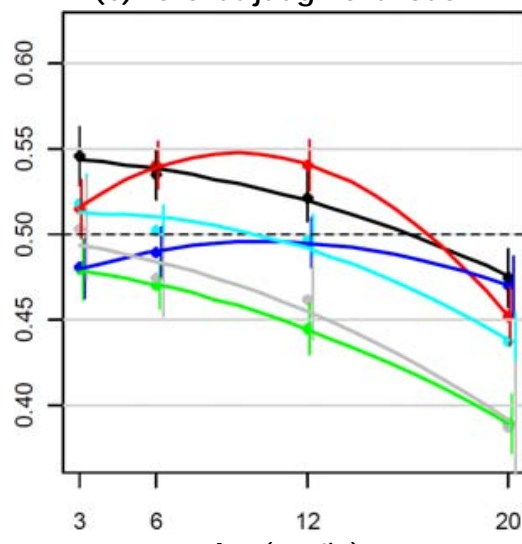

(c) Experimenter's judgment Ratio

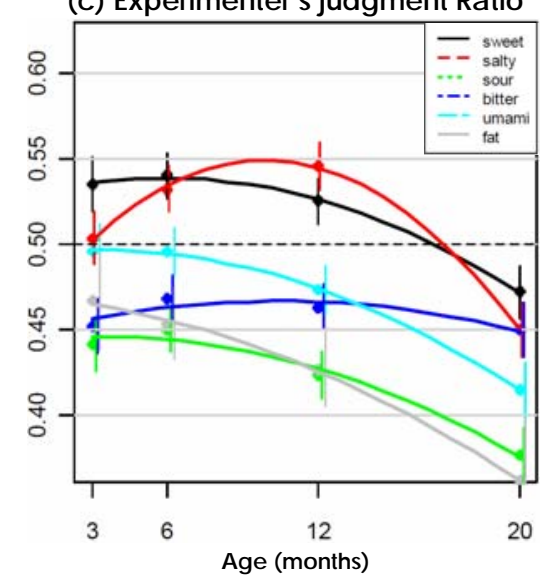
Age (months) Age (months) Age (months)
Fig. 1: Modeling the evolution of acceptance (ratios of intake (a), of parents (b) and of experimenter's judgment of liking (c)) of basic taste solutions and of a fat with a quadratic effect of age; vertical lines represent $95 \% \mathrm{Cl}$.

- For the salty taste, acceptance evolved shamly: it increased between 3 and 12 mo (at 12 mo no difference with acceptance of sweet taste)

- For the bitter taste, acceptance was stable between 3 and 20 mo.

- For the fat stimulus, there was a clear decrease in acceptance with age, from indifference at 3 mo to rejection at $20 \mathrm{mo}$.

- Larger differences between stimuli were observed at 12 mo compared to other ages.

$>$ Parent's or of experimenter's judgement of liking

- Conclusions are similar when considering ratios of parent's or of experimenter's judgement of liking and ratios of intake. However, the intake

parthe sour, bitter and umami tastes and for the fat solution compared to the more sharply negative facial expressions and other behaviors revealing rejection - The preference for sweet and salty solutions is highlighted clearly by intake ratio but not so much by parent's and experimenter's judgment of liking, suggesting that few expressions or behaviors reflecting positive affects were observable.

- The lower acceptances at 20 mo observed for all stimuli could be due to a context effect: infants have lea med to encounter fat and sweet, sour, salty and uma mi tastes in foods and not in water and thus could perceive water solutions of these stimuli as unfamiliar. Infants might be less exposed to the bitter taste in foods, explaining the sta bility of acceptance of this taste in water solution. Thus measuring acceptance of tastes in water solutions in order

to predict food preferences could be relevant at 12 mo but no more at $20 \mathrm{mo}$. to partial oxydation) and might be perceived more when infants grow older. The preference for fat may be related to leaming effect due to the energy

19th Annual Meeting of the Society for the Study of Ingestive Behavior July $12-16^{\text {th }}, 2011$ 